\title{
Monitoring of Ground Movement and Groundwater Changes in London Using InSAR and GRACE
}

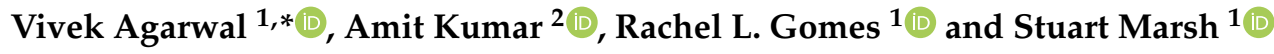 \\ 1 Faculty of Engineering, University of Nottingham, Nottingham NG7 2RD, UK; \\ rachel.gomes@nottingham.ac.uk (R.L.G.); stuart.marsh@nottingham.ac.uk (S.M.) \\ 2 School of Geography, University of Nottingham, Nottingham NG7 2RD, UK; amit.kumar@nottingham.ac.uk \\ * Correspondence: vivek.agarwal@nottingham.ac.uk; Tel.: +44-7436035061
}

Received: 2 October 2020; Accepted: 28 November 2020; Published: 1 December 2020

\begin{abstract}
Groundwater-induced land movement can cause damage to property and resources, thus its monitoring is very important for the safety and economics of a city. London is a heavily built-up urban area and relies largely on its groundwater resource and thus poses the threat of land subsidence. Interferometric Synthetic Aperture Radar (InSAR) can facilitate monitoring of land movement and Gravity Recovery and Climate Experiment (GRACE) gravity anomalies can facilitate groundwater monitoring. For London, no previous study has investigated groundwater variations and related land movement using InSAR and GRACE together. In this paper, we used ENVISAT ASAR C-band SAR images to obtain land movement using Persistent Scatterer InSAR (PSInSAR) technique and GRACE gravity anomalies to obtain groundwater variations between December 2002 and December 2010 for central London. Both experiments showed long-term, decreasing, complex, non-linear patterns in the spatial and temporal domain. The land movement values varied from -6 to $+6 \mathrm{~mm} /$ year, and their reliability was validated with observed Global Navigation Satellite System (GNSS) data, by conducting a two-sample $t$-test. The average groundwater loss estimated from GRACE was found to be $9.003 \mathrm{MCM} /$ year. The ground movement was compared to observed groundwater values obtained from various boreholes around central London. It was observed that when large volumes of groundwater is extracted then it leads to land subsidence, and when groundwater is recharged then surface uplift is witnessed. The results demonstrate that InSAR and GRACE complement each other and can be an excellent source of monitoring groundwater for hydrologists.
\end{abstract}

Keywords: PSInSAR; GRACE; surface subsidence; groundwater; London

\section{Introduction}

Groundwater contributes a significant proportion of the Earth's freshwater and a large part of the urban world is facing groundwater depletion and the problems related to it [1]. Over $40 \%$ of the public water supply comes from underground aquifers in most parts of Europe [2]. Thus, efficient management of groundwater is needed to ensure its sustainability. One of the major problems associated with over-abstraction of groundwater is land subsidence, resulting from the compression of the sub-surface aquifer system due to loss of pore pressure and/or land uplift, which is caused because of excessive groundwater recharge [3]. This land movement can cause major and recurrent harm to infrastructure, increase in floods, water contamination risks, and nonrecoverable losses in an aquifer's ability to store water. This is pertinent with globally increasing urbanisation.

The concept of an aquifer is explained in Terzaghi's theory of consolidation [4], which states that if there is variation in pore pressure of a fluid, and total vertical stress is unchanged, then the effective stress modifies correspondingly within the aquifer and thus causes a change in volume. This volume change depends on the properties of the aquifer like compressibility, permeability and field capacity. 
Additionally, the ground movement in the vertical direction results from elastic or inelastic compression, which relies on variation in the hydraulic head and thickness of the unconsolidated deposits $[5,6]$.

Chalk is the most vital aquifer in the United Kingdom (UK) as it provides approximately $60 \%$ of the groundwater consumed in the UK [7] and accounts for nearly 80\% of water supply in River Thames catchment and $20 \%$ in London alone [8]. Chalk is one of the most supervised and controlled aquifer systems in the UK and has been providing water in London for domestic and industrial use since the 19th century $[9,10]$. During the early and mid-twentieth century, a lot of groundwater abstraction took place because of anthropogenic development around central London. This abstraction led to a fall of water level to $88 \mathrm{~m}$ below sea level in the 1960s, which resulted in a depression in the water table. Due to the de-industrialization since the 1980s, the abstraction was reduced, and the groundwater recovered by $3 \mathrm{~m} /$ year in the 1990s, which lead to the rise of groundwater level. This rise in groundwater level caused a threat to infrastructure in the London basin. To check this rise, the General Aquifer Research, Development and Investigation Team (GARDIT) strategy was implemented in 1992 [11]. The GARDIT strategy was implemented using groundwater withdrawal licensing and monitoring, which stabilized the groundwater around the year 2000. Subsequently, the study of groundwater and related subsidence during the period 2002 to 2010 has been carried out here using different geospatial tools.

To map the surface movement, traditional methods like levelling, Global Navigation Satellite System (GNSS), 3D laser scanning, and similar provide accurate information, but are tedious, expensive, have low spatial extent and; therefore, are unsuited to surveying large (basin level) areas [3,12]. A better alternative is to use the Persistent Scatterer Interferometric Synthetic Aperture Radar (PSInSAR) technique, which can identify coherent and stable scattering targets and use their phase history to measure land movement. Moreover, PSInSAR can carry out independent Phase Unwrapping for each permanent scatterer and provide weather independency, sunlight independency (active sensor) and high (basin-level or greater) spatial coverage. Therefore, PSInSAR provides better accuracy and spatial resolution as compared to other traditional methods of land surveying. It has also been used by many researchers to study land movement resulting from earthquakes [13], glacial movements [14] and subsidence [12,15-17].

It is not convenient to directly estimate regional-scale water storage as it is labour intensive and expensive work. Many researchers have shown that Gravity Recovery and Climate Experiment (GRACE) gravimetry offers an alternative remote sensing tool [1,18-21], which is capable of monitoring water storage. This water may include surface water, groundwater, soil moisture, snow and ice. GRACE has emerged as a vital information source to hydrologists, as it can be used for optimal groundwater observations at a regional scale. When there is a large change in groundwater storage volume in a small area, GRACE can then detect the corresponding mass change because of its high signal-to-noise ratio [22-24]. Therefore, GRACE data can be an excellent source of monitoring the variation in groundwater storage.

To the best of our knowledge, very few attempts have been made to study PSInSAR derived land subsidence and GRACE gravity derived groundwater together $[22,25,26]$. For London, this is the first InSAR-GRACE study. The PSInSAR and GRACE are independent datasets and at different spatial resolution, hence the two datasets have not been directly correlated. The results are rather verified with observed borehole groundwater data and observed GNSS height values at various stations. In this paper, we comprehensively analysed the relationship between surface deformation and groundwater variation. We also discussed various natural and anthropogenic factors which affect both these phenomena.

\section{Study Area}

In the study, the area chosen is the administrative area of Greater London (black boundary in the Figure 1). The area is bounded by $0^{\circ} 30^{\prime} \mathrm{W}$ and $0^{\circ} 20^{\prime} \mathrm{E}$ longitudes and $51^{\circ} 42^{\prime} \mathrm{N}$ and $51^{\circ} 17^{\prime} \mathrm{N}$ latitudes, covering an area of approximately $1600 \mathrm{~km}^{2}$ in the southern part of England. 


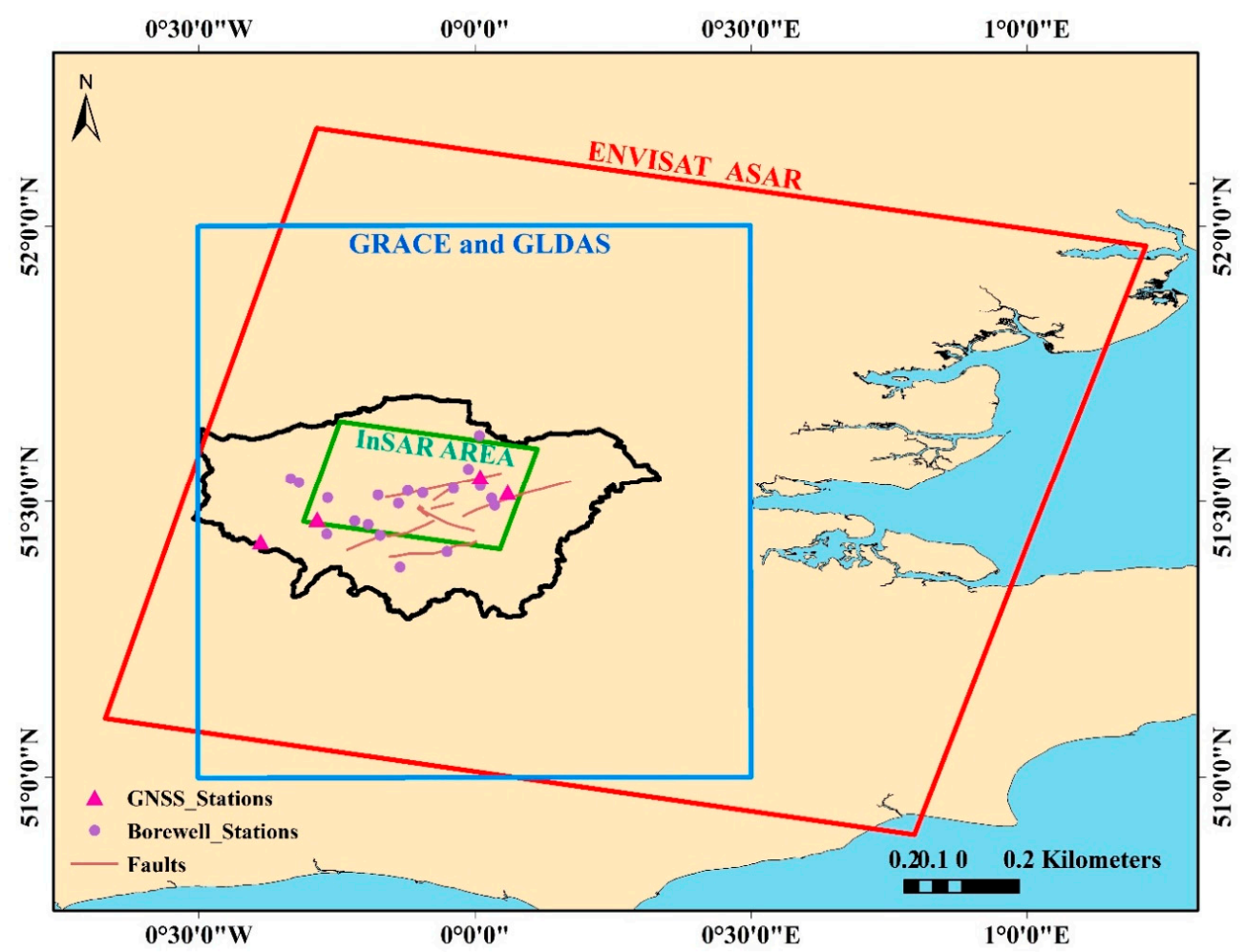

Figure 1. Study Area: Red box, blue box and green box show the extent of ENVISAT-ASAR (Environmental Satellite-Advanced Synthetic Aperture Radar) image, the extent of GRACE (Gravity Recovery and Climate Experiment) data used and InSAR (Interferometric Synthetic Aperture Radar) study area, respectively. Black boundary shows the administrative area of London. Purple dots, pink triangles and brown lines show the location of key boreholes, GNSS (Global Navigation Satellite System) stations and faults in the study area, respectively.

The London basin is infilled by younger Paleogene deposits and the chalk group forms a rim around it and has a depth exceeding $200 \mathrm{~m}$ in central London [27,28]. Table 1 summarizes the geology of the London Basin, which shows that the Bagshot formation and the Claygate member are present above the London clay. These are young deposits and form nearly $50 \%$ of the geology of the basin. London clay is densely fissured and has a blue-grey texture, and beneath this is the Harwich formation which is mainly made of sand and gravels. Then comes the Lambeth group, which consists of sands, silts and clays. The Cretaceous era is mainly marked by chalk deposits, which forms one of the most important geological formations in the UK, as it accounts for the majority of the groundwater used in the country. The chalk aquifer provides approximately $60 \%$ of the groundwater used in the country [29] and also is a source for nearly $80 \%$ of public water supply in the catchment area of the River Thames and approximately $20 \%$ in London [30].

Table 1. Geology of the London Basin (adapted from EA (Environment Agency) status report 2010 [11]).

\begin{tabular}{cccc}
\hline Era & Group & Formation & Thickness (m) \\
\hline \multirow{3}{*}{ Thames } & Bagshot Formation & $10-25$ \\
& & Claygate Member London Clay & $30-90$ \\
\cline { 3 - 4 } & & Harwich Formation & $0-10$ \\
\cline { 2 - 4 } & \multirow{2}{*}{ Lambeth } & Woolwich and Reading Beds & $10-20$ \\
& & Upnor Formation & $5-7$ \\
\cline { 2 - 4 } Cretaceous & & Thanet Sands & $0-30$ \\
\hline
\end{tabular}


The water supply in London for public and industrial use [10] is mainly provided by the chalk group aquifer and it also provides significant base flow to the Thames, with a base flow index of 0.63 [8]. Even though the Paleogene group are not the main deposits, they confine the underlying chalk aquifer around central London. These provide a heterogeneous nature to the hydrogeology of the region and a good amount of groundwater can be present in sand-rich horizons. The study of the hydrogeology of central London and the response of the chalk aquifer to faulting by different researchers have highlighted that different permeability of faults results in irregular groundwater flow $[9,31]$. Th infrastructure and lithology can cause ample pressure on the properties of the chalk aquifer in the Thames basin [32], and chalk has a porosity of dual-medium with matrix and fracture [33,34]. When the groundwater level declines then most flow occurs in fractures and storage occurs in a matrix. The chalk aquifer's primary porosity is between $0.25-0.40$, which is due to the coccoliths found in the aquifer, which does not allow water to drain easily as the pore throats are tiny $[35,36]$ and hence groundwater storage of the Thames aquifer is mainly secondary porosity along faults.

According to the Copernicus EEA European urban atlas (UA), the land use within the London area is dominated by dense to medium density urban fabric with multiple industrial units and stretched port areas along the river Thames [37]. Additionally, according to the 2011 population census of the UK, the total population of London is around 9.5 million and has been continuously increasing since the 1980s. The ever-increasing population is exerting a pressure on groundwater to meet the increasing demand and thus can cause the problem of land subsidence.

\section{Materials and Methods}

This study used InSAR, boreholes, GNSS, GRACE and Global Land Data Assimilation System (GLDAS) data obtained from various sources. The specifications of data used is summarised in Table 2 and the overall methodology used in this study is shown in Figure 2.

Table 2. Data and software used.

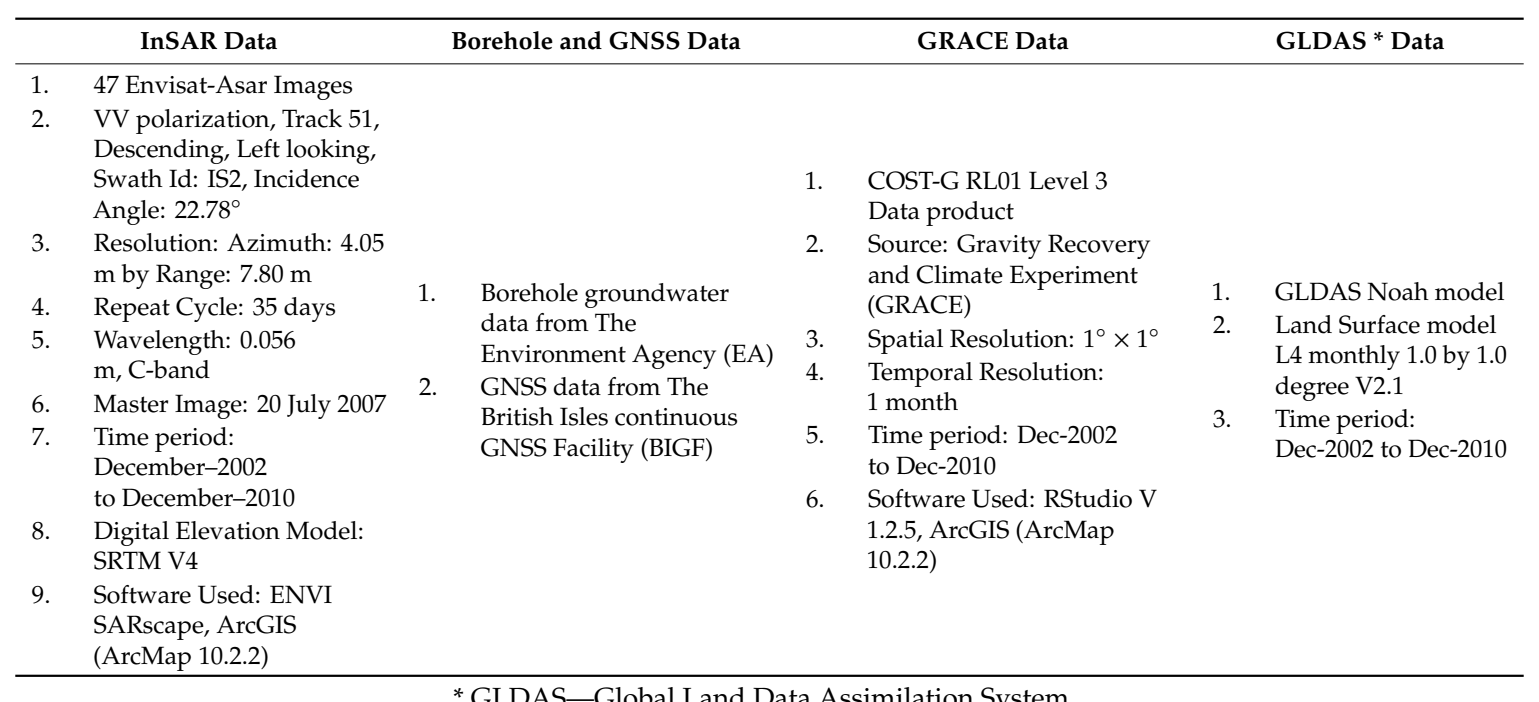

The methodology mainly involved processing of InSAR data to calculate land subsidence/uplift using PSInSAR principle and validating the InSAR results using GNSS data. It also involved calculating change in groundwater level using GRACE anomalies and GLDAS models. Finally, land subsidence/ uplift and groundwater variation were correlated and studied in conjunction. The study was carried out for the time period between December 2002 to December 2010 in London. 


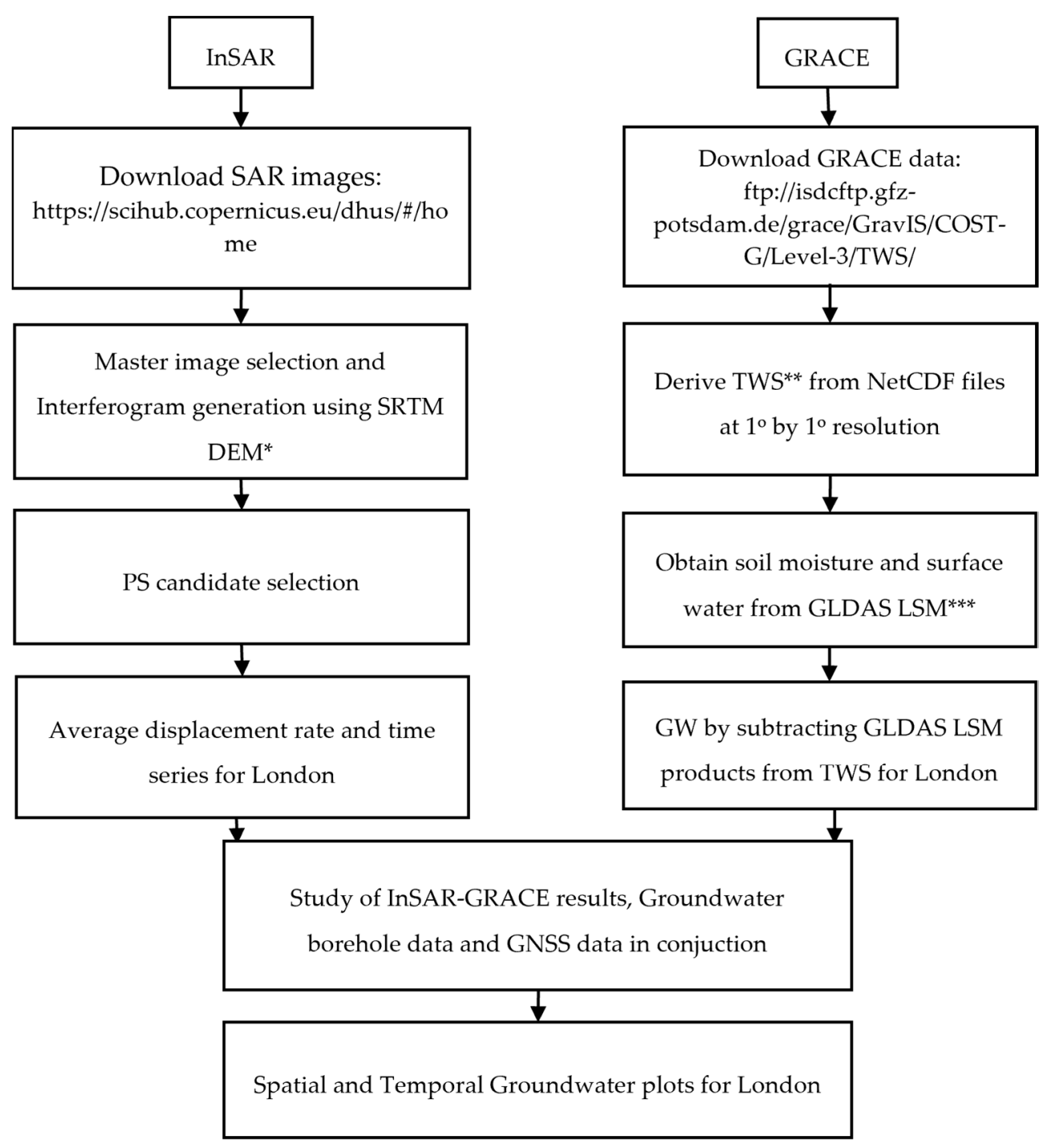

Figure 2. Methodology used for the research. (* SRTM DEM-Shuttle Radar Topography Mission Digital Elevation Model, ${ }^{* *}$ TWS-Terrestrial Water Storage, ${ }^{* * *}$ LSM-Land surface Model).

\subsection{Subsidence from PSInSAR}

The Interferometry Synthetic Aperture Radar (InSAR) provides the possibility to map the movement of the Earth surface with high accuracy. SAR data pairs with good coherence are required for informative interferogram generation. InSAR calculates the phase difference between various SAR acquisitions taken from the same orbital track. Persistent Scatterer InSAR (PSInSAR) differs from conventional interferometry as it only uses pixels that show stability in phase for several interferograms. These stable pixels can be termed as Persistent Scatterers (PSs) or permanent scatterers [38]. The PSInSAR time series analysis allows us to do the following:

1. Allow better selection of coherent pixels;

2. Atmosphere/orbit errors can be reduced by filtering in space and time;

3. Make DEM (Digital Elevation Model) error estimation possible;

4. Make the most reliable phase unwrapping possible (3D);

5. Make sub-pixel resolution possible.

The inclination of ENVISAT-ASAR satellite ground tracks at the SAR scene centre was $14^{\circ}$ in the south-north axis at the latitude of London, and the incidence angle of the employed sensor modes was 
$23^{\circ}$ measured from the vertical direction. This means that the employed LOS could estimate purely vertical motions as approximately $92 \%$ of their actual amount, E-W motions as approximately $38 \%$ and N-S as only approximately $9 \%$ [39].

The PSInSAR analysis in ENVI Sarscape [40] is a semi-automated process and involves multiple steps. The first step is to select a master image, with reference to which all other slave images are co-registered. The master image is selected based on the minimum mean baseline of the stack, which means that the image should have an ideal temporal and spatial position with respect to the other ones. This simplifies data co-registration and provides higher coherence, as small baselines are less sensitive to volume de-correlation [41].

To select the reference point, the PS algorithm in SARscape follows one of the two following principles: (a) If the area is larger than a given surface threshold, the whole image is divided in more subsets (considering an overlap) and each one will be processed separately with an own reference point, otherwise too many parameters should be estimated and the atmosphere estimation would become less accurate. So, in the final step, all single areas will be mosaicked. (b) On the other hand, if the area is smaller than this surface threshold, one reference point is sufficient, and the image will not be divided. This surface threshold is called "Area for Single Reference Point (sqkm)". In our case this value was $25 \mathrm{~km}^{2}$ and the first principle was followed. In total there were 63 ground control points.

After co-registration, interferograms were generated for each slave image using the same master image. Then interferogram flattening was performed using a reference DEM SRTM V4. The better the reference DEM accuracy (or resolution) the better the result in terms of topography removal. Then first step inversion was performed to derive the coherence, displacement velocity and residual topography, which were used to flatten the complex interferograms. Then the second inversion step was performed to address the atmospheric phase components of the linear model products coming from the first inversion. Then, finally, the PS products were geocoded to display the velocity maps in both raster and vector formats.

\subsection{Groundwater from $G R A C E$}

GRACE (Gravity Recovery And Climate Experiment) is a combined venture of the National Aeronautics and Space Administration (NASA), USA and the German Aerospace Center (DLR) [42]. It was launched on a rocket launch vehicle from the Plesetsk cosmodrome in Russia on 17 March 2002. The mission was operated by the German Space Operations Center (GSOC) and it consisted of two identical satellites named GRACE-A and GRACE-B. With over 15 years of operation, the predicted mission lifetime of 5 years was exceeded by more than 3 times and ended on October 2017. The GRACE Follow-On (GRACE-FO) is a sequel of the mission on almost similar hardware and was launched in May 2018.

A change in the mass of the Earth surface causes a change in gravity. This mass change can be assumed to be mainly concentrated near the earth surface in a shallow layer of a thickness of water. The monthly gravity changes mainly result from changes in water content in hydrologic reservoirs, atmospheric and land ice masses and by mass exchanges between the Earth system's compartments [43]. Thus, after postprocessing and applying corrections for non-water mass changes, GRACE gravity anomalies can provide the Terrestrial Water Storage (TWS) variation.

TWS was obtained using COST-G, RL01, level-3 data [44] filtered with VDK5 and VDK3 anisotropic filters [45]. The deterministic components from VDK5 were combined with residual monthly variations from VDK3, to account for noise level of seasonal components. To calculate TWS, stokes coefficients were used to invert mass anomalies by applying thin layer approximation [43]. To reduce the effect of atmospheric mass variability, the non-tidal de-aliasing product AOD1B RL06 [46] was used for processing of level 2 monthly gravity fields. The signal estimates were accompanied by TWS standard deviations, which represents associated uncertainties that take into account the varying noise level from month-to-month. The uncertainty was simulated using the empirical covariance model, which considers non-stationarity, non-homogenous and anisotropic structures of spatial correlations. 
The final Groundwater Storage Change ( $\triangle$ GWS) could then be calculated by subtracting surface water storage, soil moisture and snow and ice water storage from TWS.

$$
\Delta \mathrm{GWS}=\Delta \mathrm{TWS}-(\Delta \mathrm{SWS}+\Delta \mathrm{SMS}+\Delta \mathrm{SIS})
$$

where $\Delta \mathrm{TWS}$ is the change in terrestrial water storage, $\Delta \mathrm{SWS}$ is the change in surface water storage, $\Delta \mathrm{SMS}$ is the change in soil moisture storage, and $\Delta \mathrm{SIS}$ is the change in snow and ice water storage.

The surface water and soil moisture were used from a monthly GLDAS Land Surface Model (LSM). GLDAS drives four LSMs, namely NOAH [47], Community Land Model (CLM) [48], MOSAIC [49], and Variable Infiltration Capacity (VIC) [50]. To minimize any inherent deficiency in any model, an average of four LSM hydrological outputs from NOAH, CLM, MOSAIC and VIC were adopted for our study time period. The change in snow and ice cover was considered negligible given the climatic scenario of London city. To ascertain that spatial resolution of TWS provided by GRACE is consistent with SWS and SMS provided by GLDAS, the kriging interpolation was adopted to resample the GLDAS data with the same resolution as the GRACE data.

\section{Results}

\subsection{InSAR Results}

Figure 3 shows the Line of Sight (LOS) average land deformation map for central London acquired from 47 ENVISAT-ASAR images from December 2002 to September 2010, where positive values suggest that the surface is moving towards the sensor (uplift) and the negative values suggest that the surface is moving away from the sensor (subsidence). To analyse the multi-temporal InSAR monitoring results, we can look at the statistical deformation results of the entire area through the number of persistent scatterer points (PSNs), mean rate of deformation (MRD), and standard deviation (SD) of deformation (Table 3).

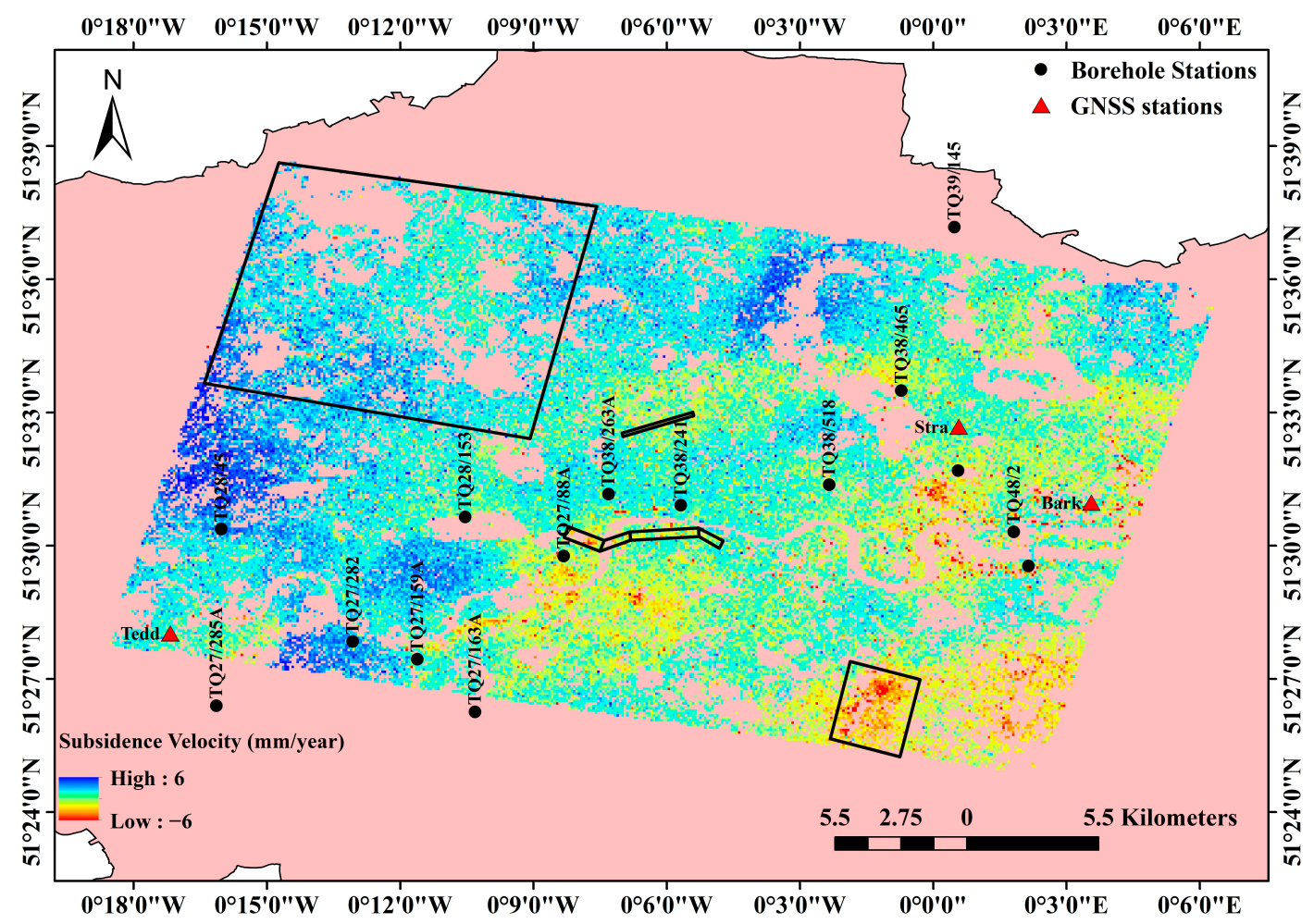

Figure 3. Line of Sight (LOS) average land deformation map for central London (blue areas depict uplift, while the red areas depict subsidence) with the location of observed boreholes (black dots), observed GNSS stations (red triangle) and four land movement sites (black boxes, detailed in Figure 8a-d). 
Table 3. Statics of PSInSAR (Persistent Scatterer InSAR) subsidence.

\begin{tabular}{ccccccc}
\hline Time Period & $\begin{array}{c}\text { PS } \\
\text { Number }\end{array}$ & $\begin{array}{c}\text { Area } \\
\left.\mathbf{( k m}^{2}\right)\end{array}$ & $\begin{array}{c}\text { PS Density } \\
\text { (PS/km²) }\end{array}$ & $\begin{array}{c}\text { PS Coherence } \\
\text { Threshold }\end{array}$ & $\begin{array}{c}\text { MRD } \\
\text { (mm/Year) }\end{array}$ & $\begin{array}{c}\text { SD } \\
\text { (mm/Year) }\end{array}$ \\
\hline $\begin{array}{c}\text { December 2002 to } \\
\text { September 2010 }\end{array}$ & 490,969 & 987 & 497 & 0.75 & -0.18 & 0.665 \\
\hline
\end{tabular}

London has mostly urban areas, which makes it highly suitable to study land movement using PSInSAR data, but open areas such as land, parks, etc., are not captured by PSInSAR properly. The PS density depends on the coherence threshold, and the selection of optimum coherence threshold depends on the desired quality and number of persistent points in the resulting subsidence velocity map. A coherence threshold of 0.75 was chosen, which resulted in PS density of $497 \mathrm{PS} / \mathrm{km}^{2}$. Locally, the displacement velocities and directions (towards or away from the satellite) obtained at PS points can differ because of construction, road resurfacing, localised settlement, etc., but small-scale regional patterns are discernible geographically regardless of these high magnitude changes.

When land subsidence or uplift of an area is less than or equal to $\pm 10 \mathrm{~mm} / \mathrm{year}$, the area can be termed as stable according to the theory of mining subsidence [3]. From Figure 3, it can be seen that the surface deformation varies from -6 to $+6 \mathrm{~mm} / \mathrm{year}$, hence we can consider our study area to be stable during our observed time period. Additionally, it can be observed that uneven subsidence is prominent but that there are contiguous blocks of movement in a consistent direction (either uplift or subsidence). The area to the south of River Thames is mainly subsiding, while the area to the north is mainly rising. The main reason for this pattern can be attributed to the groundwater changes, sub-surface excavations for various construction activities and the subsurface geology. For example, there is uplift across the London clay adjacent to the south of River Thames, where white to grey chalk is present at the surface. Clays, some sands and gravels of the Lambeth Group and silts and sands of the Thanet Sand formation are present at the surface between the areas of London clay and chalk [51]. The subsidence near the Thames can be mainly attributed to compressible ground material such as alluvium.

The average temporal land movement for the entire study area (Figure 4) is showing continuous negative movement, so the area is subsiding slowly for our study period. It can also be verified by the fact that the average mean rate of deformation is $-0.18 \mathrm{~mm} /$ year (Table 3). However, it can also be seen that there is an imperfect cyclic rise and fall of the land surface with a negative trend. This behaviour is probably because of seasonal and annual variations, which might be attributed to groundwater changes and the presence of compressible materials. This overall subsidence pattern can be attributed to the fact that the area has Holocene deposits of alluvium in the flood plains of the River Thames and the River Lea. These overlay deposits are of the London clay formation, Lambeth group, Thanet sand formation, Seaford chalk formation and Newhaven chalk formation. These Holocene alluviums are prone to slowly compact, dry and compress, if there is removal of groundwater, and thus can lead to subsidence.

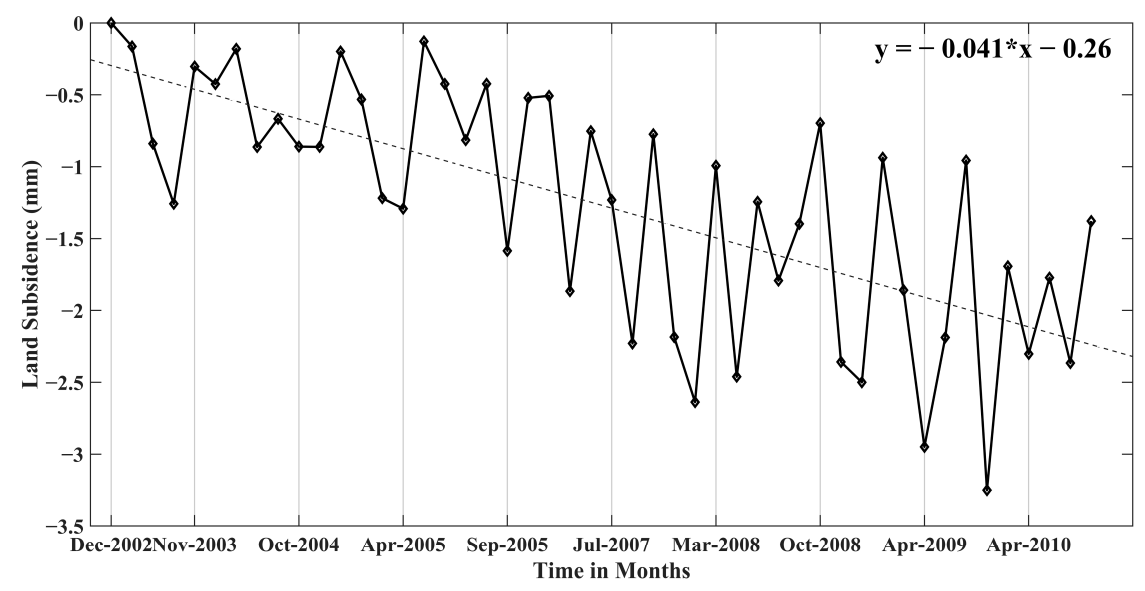

Figure 4. Time series of average subsidence for central London. 
The standard deviation of average velocity for all the Persistent Scatterers (PSs) obtained from PSInSAR range from 0.45 to $10.5 \mathrm{~mm} /$ year. The statistical analysis suggests that the standard deviation is less than $3 \mathrm{~mm} /$ year for $75.34 \%$ of the monitoring points and less than $5 \mathrm{~mm} /$ year for $98.22 \%$ of the monitoring points (Figure 5), which suggests that the land displacement monitoring accuracy using the Envisat-ASAR PSInSAR is high. The accuracy of PSInSAR results is further validated using observed GNSS data by two sample $t$-test and discussed in Section 5.1.

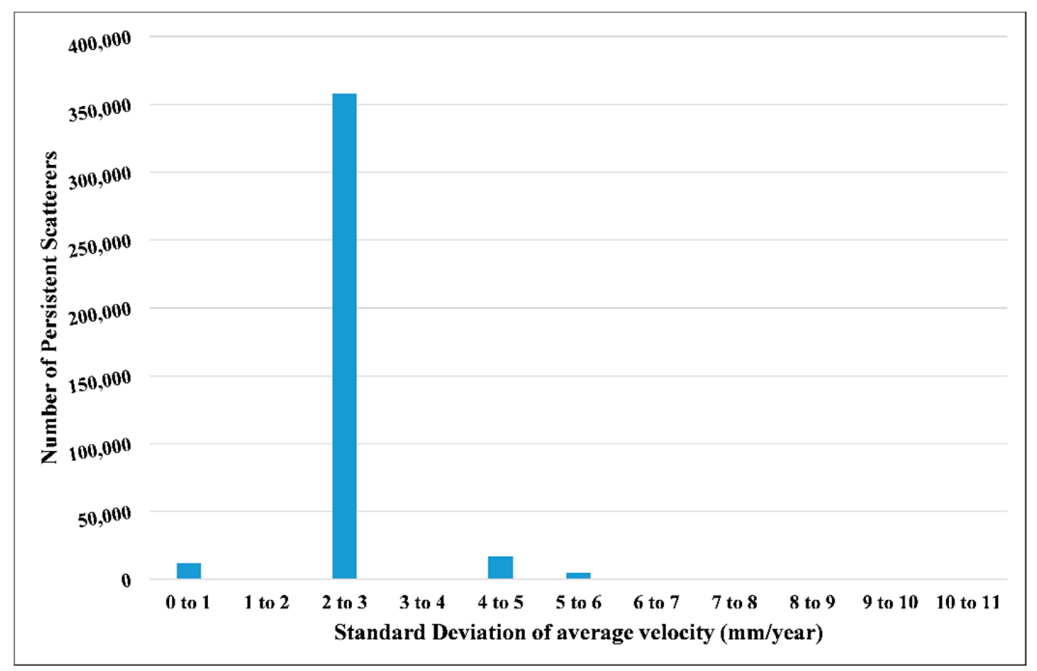

Figure 5. Standard deviation distribution of average subsidence velocity (mm/year).

\subsection{GRACE Results}

The primary aim of the GRACE mission was to map gravity variations and infer corresponding hydrological redistributions. The small timeframe mass variations occurring at or near the Earth's surface are much greater than those taking place deep inside the Earth [52], and hence GRACE anomalies can be related to hydrology after removing the contribution of atmospheric masses from air pressure data. The spatial and temporal groundwater variations from GRACE results are shown in Figure 6a,b, respectively. Only four representative points could be observed for our study area, owing to the poor spatial resolution of GRACE. The spatial variations map (Figure 6a) was made by IDW interpolation of the representative points. The temporal series (Figure $6 \mathrm{~b}$ ) was made by averaging all the points in Figure 6a.

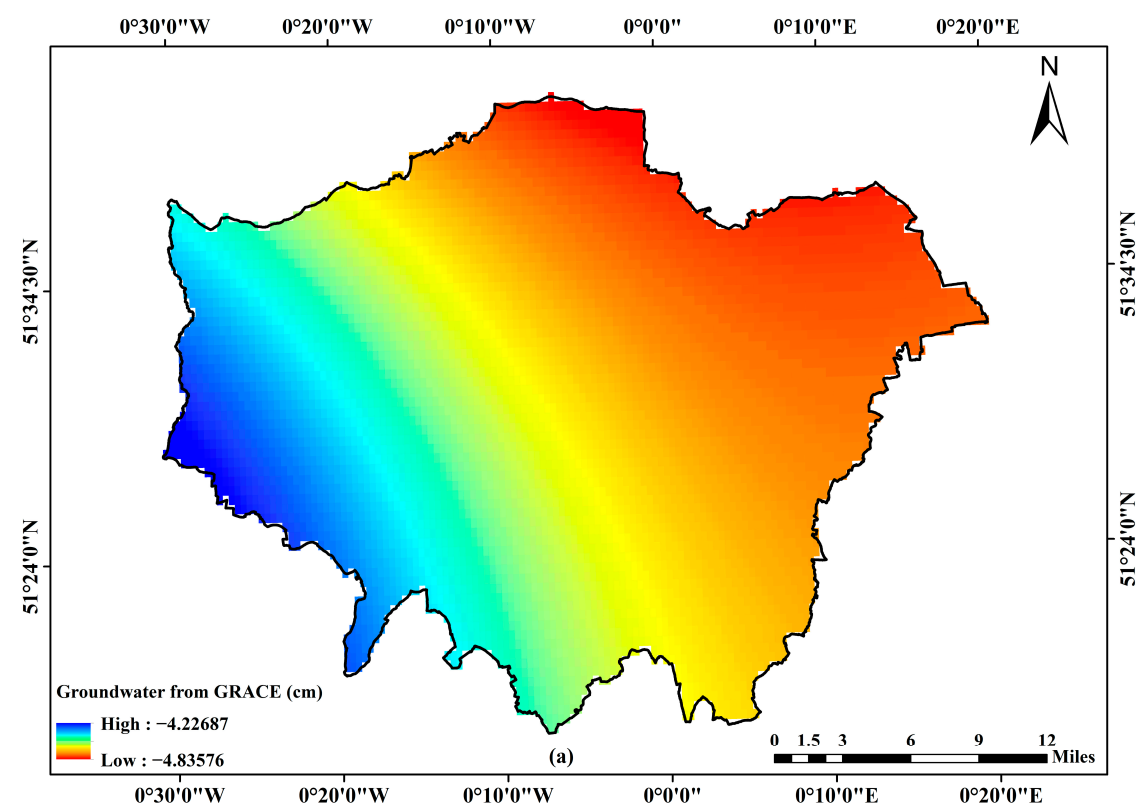

Figure 6. Cont. 


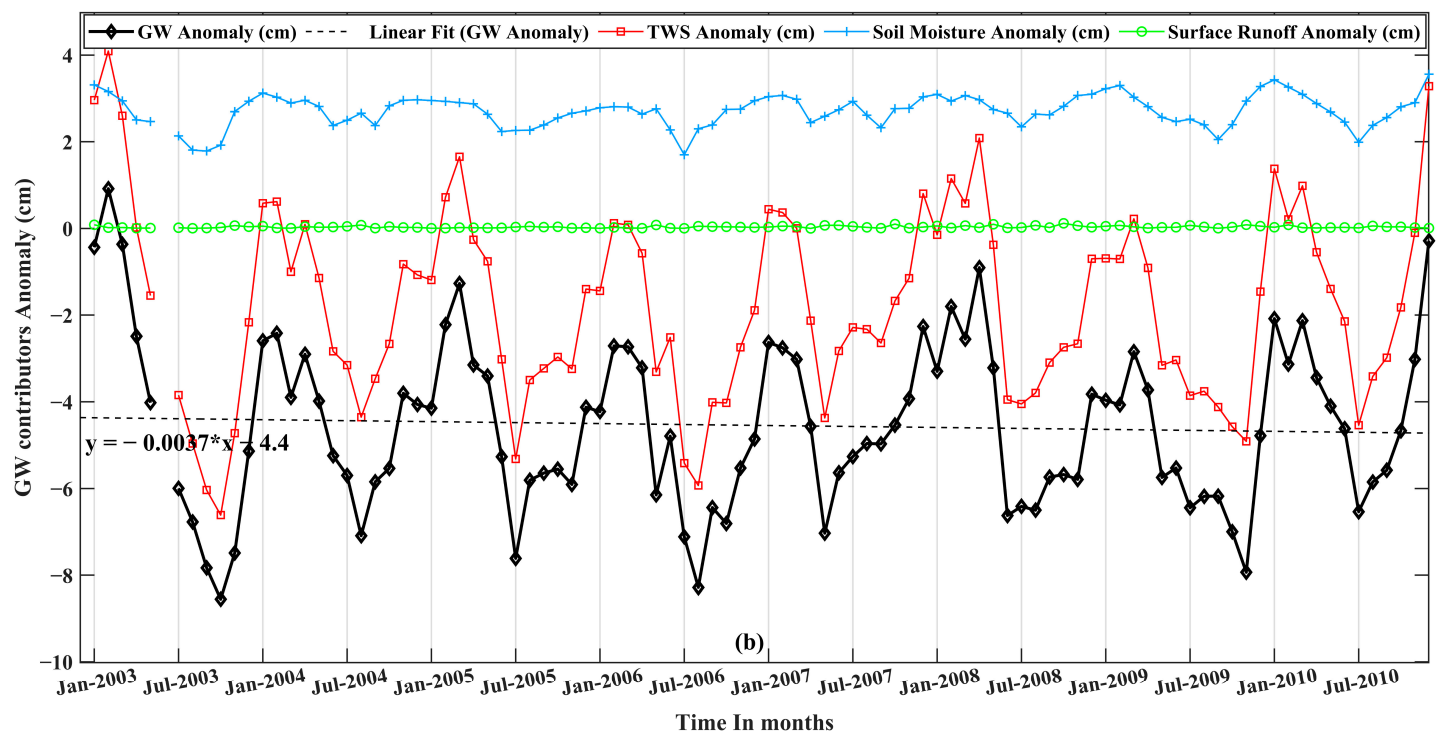

Figure 6. (a) Spatial variation of groundwater from GRACE (the red zones signifies larger groundwater depletion as compared to the blue zones). (b) Temporal variation of Terrestrial Water Storage (TWS) from GRACE (red line), soil moisture (blue line) and surface runoff (green line) from GLDAS, resulting in groundwater (black line) and linear fit for groundwater (black dotted line).

From the spatial variations map (Figure 6a), the total average groundwater over the observed time period seems to be decreasing from the north-western region to the south-eastern region. In Figure 6a, the red zones signifies more groundwater depletion as compared to the blue zones. From the temporal series (Figure 6b), it can be observed that the major contribution to Terrestrial water Storage (TWS) is from groundwater and the contribution from soil moisture and surface runoff is relatively small, thus TWS can be taken as a good representation of groundwater. The slope of best-fit line for the groundwater variation is negative, which indicates that, overall, there is groundwater depletion with time. This overall groundwater is reducing mainly due to the urban fabric of London city. The ever-increasing population exerts pressure on groundwater resource, which leads to its depletion. However, temporal rise and fall in groundwater can be seen, which can be attributed to seasonal and annual changes. A general trend which can be observed is rise in groundwater in winter months around January-February, and fall in groundwater in summer months around June-August.

Table 4 summarises the results from spatial groundwater variations from GRACE. On averaging groundwater change over Figure 6a, a value of $-4.547 \mathrm{~cm}$ over London for an area of $1584 \mathrm{~km}^{2}$ is observed. The uncertainties associated with this was calculated from accompanied TWS standard deviations and showed an average value of $\pm 2.1 \mathrm{~cm}$. Thus, a total of 72.024 million cubic meter (MCM) groundwater deficit is estimated from January 2003 to December 2010, which gives an average value of $9.003 \mathrm{MCM} /$ year. This is approximately 17 times less than the groundwater mass loss for Mexico around the same time period [25].

Table 4. Groundwater variations from GRACE.

\begin{tabular}{cccc}
\hline $\begin{array}{c}\text { Study Area } \\
\text { Extent }\end{array}$ & $\begin{array}{c}\text { Average (Spatial) } \\
\text { GW Change }\end{array}$ & $\begin{array}{c}\text { Average Volumetric } \\
\text { (Spatial) GW Change }\end{array}$ & $\begin{array}{c}\text { Average Yearly GW } \\
\text { Change }\end{array}$ \\
\hline $1584 \mathrm{~km}^{2}$ & $-4.5471 \mathrm{~cm}$ & $-72.024 \mathrm{MCM}$ & $-9.003 \mathrm{MCM}$ \\
\hline
\end{tabular}

In the early 1990s, the Environment Agency (EA) implemented the General Aquifer Research, Development and Investigation Team (GARDIT) strategy to control the groundwater level rise in the chalk aquifer under central London resulting from the previous relocation of industries from central London. GARDIT strategy issued licenses to abstract groundwater from London and by the early 
2000 's the rise in groundwater had been stabilized. The yearly data for groundwater abstraction and recharge for north London and groundwater abstraction data for the whole chalk aquifer of the London area is provided by EA [11].

The EA report suggests total groundwater abstraction of $30.480 \mathrm{MCM}$ and a total recharge of 15.520 MCM between 2003 and 2010, which amounts to 50.91\% recharge as compared to abstraction. The report also suggests an overall abstraction of 245.311 MCM groundwater from London chalk aquifer for our study period and, assuming the same recharge rate of $50.91 \%$ as north London, the total recharge for London chalk aquifer is estimated as $124.887 \mathrm{MCM}$, which results in a groundwater deficit of $120.423 \mathrm{MCM}$. The groundwater deficit as suggested by GRACE is $72.024 \mathrm{MCM}$, which is only $~ 60 \%$ of the same as suggested by the groundwater monitoring estimated by EA. Thus, around $40 \%$ of the deficit estimated by EA is not sensed by GRACE. This shows that even though GRACE data is freely available, and it proves to be a suitable alternative to costly, spatially restricted microgravity surveys, it may not precisely quantify water variations for typical aquifer scales. Despite this, it gives a clear "big picture" indication of spatial variation for total groundwater induced mass variations, which is an appropriate input for setting broad regional or national policies [53], a view for which our study provides further evidence.

\section{Discussions}

\subsection{Validation of InSAR Subsidence with GNSS Data}

To validate the reliability of results obtained from PSInSAR, we studied the PSInSAR results in comparison to GNSS data obtained from The British Isles continuous GNSS Facility (BIGF). The BIGF Level 2 products are a time series of the station-specific daily coordinate estimates obtained from the processing of continuous GNSS data, which have been subject to time series analysis to represent them as Cartesian differences or north, east, up differences (from an assumed reference coordinate at the central epoch) such that the "up" differences can be compared with PSInSAR-derived subsidence results. To verify PSInSAR subsidence results with the GNSS data, several steps were performed:

- The average monthly data sets were obtained by averaging the daily data for a particular month.

- The overlapping period for GNSS and InSAR image data were selected for each GNSS station.

- To get the subsidence at the location of the GNSS station, the average of all the persistent scatterers that are present within $300 \mathrm{~m}$ of the GNSS station was used. This was done as getting PS point and GNSS station at the exact same location may not always be possible, and also GNSS up values will be affected by its nearby areas, and hence it is suitable to take the contribution of nearby points for a particular GNSS station.

- Two-sample paired $t$-test (at 95\% confidence limit) was done on each station to test the null hypothesis that the mean difference between the two sets is zero.

The location of GNSS stations is shown in Figures 1 and 3. We discussed subsidence patterns for three GNSS stations, namely Bark, Stra and Tedd, because data available from these stations overlap with our InSAR data both spatially and temporally. Figure 7a-c highlights that both the InSAR-derived subsidence and GNSS up values exhibit a non-linear pattern.

In Figure 3, the region surrounding Bark station has a red-yellow patch and exhibits average subsidence of approximately $5 \mathrm{~mm} /$ year. The time variation of InSAR subsidence and GNSS up values from December 2002 to September 2010 at Bark station are shown in Figure 7a. Both the series exhibit similar patterns with negative subsidence, which means that the bark station is subsiding with some seasonal variations. To check whether the differences between the two series are within the acceptable range, we carried out the two-sample $t$-test. Table 5 shows the results of two-sample $t$-test for Bark, Tedd and Stra stations. For each of the stations, the mean difference is not the same, but it is important to check if this difference is statistically significant to conclude whether our PSInSAR results are in agreement with observed GNSS results or not. For two-sample paired $t$-test, we took the null 
hypothesis and alternate hypothesis as: Null Hypothesis $\left(\mathrm{H}_{0}\right): \mu=0$, the mean difference is zero and alternate Hypothesis $\left(\mathrm{H}_{\mathrm{A}}\right): \mu \neq 0$, the mean difference is not zero.
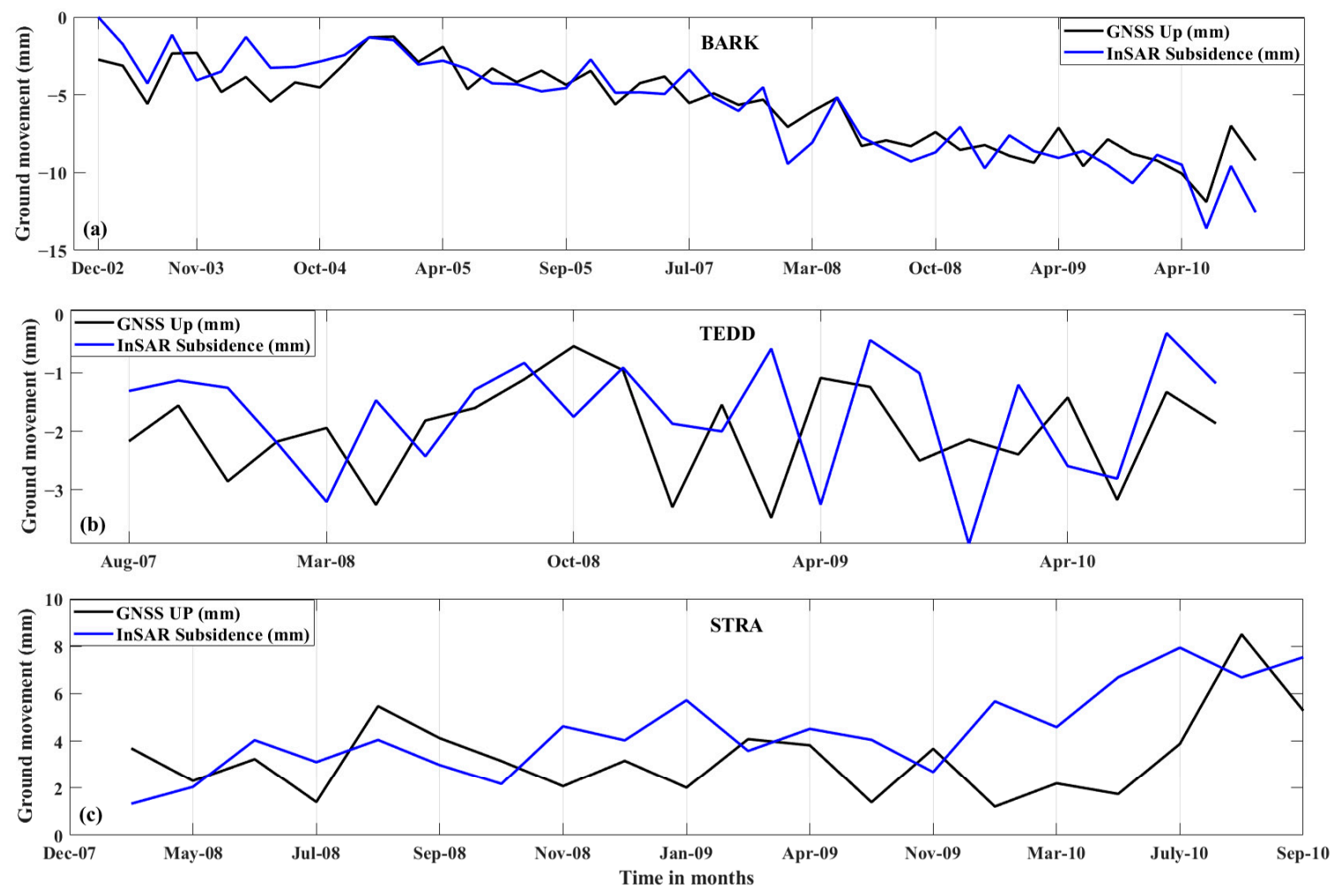

Figure 7. Time series comparison for InSAR subsidence and GNSS up values at (a) Bark (b) Tedd and (c) Stra stations.

Table 5. Two-paired $t$-test for GNSS and InSAR land movement.

\begin{tabular}{cccc}
\hline Parameter & BARK & TEDD & STRA \\
\hline Mean (UP) & -5.707 & -1.978 & 3.318 \\
Mean (INSAR Sub) & -5.753 & -1.696 & 4.400 \\
Variance (Up) & 6.788 & 0.673 & 3.018 \\
Variance (InSAR Sub) & 10.687 & 0.933 & 3.372 \\
Observations & 48 & 23 & 20 \\
Pearson Correlation & 0.903 & 0.033 & 0.218 \\
Hypothesized Mean Difference & 0 & 0 & 0 \\
Df (degree of freedom) & 47 & 22 & 19 \\
t Stat & 0.221 & -1.083 & -1.287 \\
$p$ (T <= t) two-tail & 0.825 & 0.290 & 0.043 \\
t Critical two-tail & 2.011 & -0.281 & 2.093 \\
Mean difference & 0.046 & -0.281 & -1.082 \\
St. Deviation of difference & 1.444 & 1.246 & 2.234 \\
Standard error of difference & 0.208 & 0.259 & 0.499 \\
T alpha half 95\% CI & 2.011 & -1.083 & 0.111 \\
Lower confidence limit & -0.373 & -0.563 & -1.138 \\
Upper confidence limit & 0.465 & 0 & -1.026 \\
\hline
\end{tabular}

From the observed results, we are mainly interested in the $t$-value that we calculated, and at Bark it is 0.221 . This signifies that these results are occurring about 0.22 standard deviations away from the mean. To accept the null hypothesis, $t$-value less than critical $t$-value ( 2.011 for Bark) is required. The $t$-value for Bark is less than the critical $t$-value, signifying acceptance of null hypothesis, showing no significant difference between the average monthly up and InSAR subsidence. Another way is to look 
at $p$-value ( 0.825 for Bark) and alpha ( 0.05 for $95 \%$ confidence limit). For the stations, a $p$-value greater than alpha null hypothesis is accepted. Thus, acceptance of null hypothesis shows that subsidence indicated by InSAR and GNSS is consistent at Bark. Similarly, $t$-value for Tedd and Stra are -1.08 and -1.28 , respectively, while critical $t$-values for Tedd and Stra are -0.28 and 2.09 , respectively. Additionally, the $p$-value for Tedd and Stra are 0.0337 and 0.2188 , respectively, which are both higher than alpha (0.05). Therefore, we have enough evidence that subsidence indicated by PSInSAR are consistent and agree very well with observed GNSS up values for all the three observed stations.

\subsection{Site-Specific Ground Movement and Its Possible Reasons}

The analysis of site-specific monthly subsidence velocity revealed a complex pattern of movements. Multiple sites show abrupt changes and indicate distinct land movement which might be induced by changes in groundwater, fault-controlled or dominated by various other controlling factors. The tributaries of the River Thames form a dense drainage network which directly affects the topography, geomorphology and geology of the study area. Additionally, the study area has flood plains containing alluvium, clay areas, open sandy layers, landslide gradients and deep-seated underground tectonic constructions, making the land surface prone to displacements. In Figure 8a-d, land movement patterns for different sites were identified and reasons for such movements are discussed below. These sites were selected based on distinct land movement pattern and available literature.
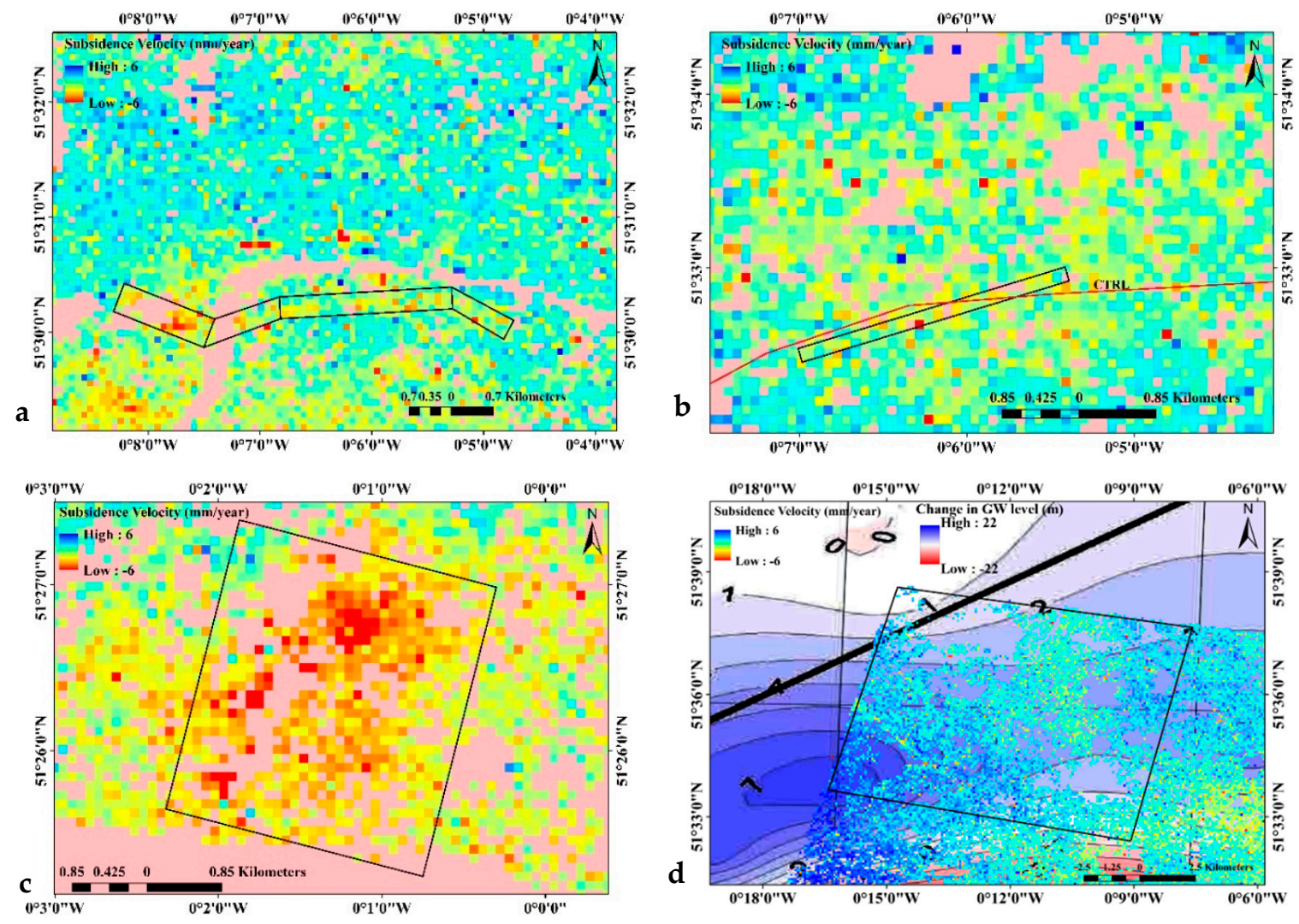

Figure 8. PSInSAR site specific subsidence maps for London. (a) Area crossing Thames river; (b) area on the north of Thames river and passing through CTRL (Channel Tunnel Rail Link); (c) area on the south of Thames river showing distinct subsidence; (d) area on the north of Thames river overlaid on groundwater contour provided by EA.

In the Figure 8a, the area marked covers $1.63 \mathrm{~km}^{2}$ and crosses multiple important anthropogenic structures like Westminster Bridge above the River Thames, the Commonwealth Secretariat, Supreme Court and Parliament Square, Waterloo train station, Nelson square, London Bridge station, 
Buckingham Palace, London Eye, and sections of the British rail network. This area is a low-lying river flood plain with elevations between 5 to $10 \mathrm{~m}$ above Ordnance Datum (mOD), and the bedrock geology is dominated by the London clay formation. Superficial deposits in the area include alluvium, peat, Kempton park gravel formation, Langley silt member and Taplow gravel formation. This area also coincides with the location of the Jubilee Line extension, which was constructed between 1993 and 1999 [54]. The total number of PS points obtained within the area marked are 3131, and the average land movement for all the PS points is $-0.87 \mathrm{~mm} /$ year, where the negative sign shows land movement away from the sensor, therefore subsiding. This subsidence in Figure 8a, can be attributed to the continuous effect of subsurface construction works, which were carried out for the Jubilee Line extension and compression of alluvium because of groundwater abstraction.

The area marked in the Figure $8 \mathrm{~b}$ spans over $0.29 \mathrm{~km}^{2}$ and crosses multiple important anthropogenic structures like Highbury and Islington station, Canonbury station, Alwyne Castle and, St. Andrew church. It also lies along the path of Channel Tunnel Rail Link (CTRL), which is a high speed 1 (HS1) railway, joining the Channel Tunnel and London (operational since 2007). The total number of PS points obtained within the area marked are 323 and the average land movement for all the PS points is $-0.83 \mathrm{~mm} /$ year. The part of CTRL track between Caledonian Road and Canonbury (area marked) was constructed during our study period. We can attribute the land movement of the area marked to the construction of CTRL and to the possible compaction of subsurface particles around the tunnel along its track. Our results are in close agreement with the results obtained by PanGeo Project [39], as the authors obtained subsidence rates of $-1.09 \mathrm{~mm} /$ year around the same area, marked as PGGH_London_015.

The area marked in Figure $8 \mathrm{c}$ is a heavily built-up area and contains buildings, roads and other man-made structures. It contains the train-line between Beckenham Hill, Bellingham and Catford. It contains other important structures like Kings church, schools, hospitals and large residential areas. Additionally, the area contains around 38 boreholes, from which groundwater is directly pumped out to meet the local requirements. Groundwater is abstracted from these boreholes through the chalk aquifer at depths in excess of $70 \mathrm{~m}$. The area marked has an extent of $6.25 \mathrm{~km}^{2}$ and contains 4319 PS points. The average subsidence for the region is $-1.95 \mathrm{~mm} /$ year and, since no other explanation for this subsidence could be identified, it appears groundwater abstraction has caused the area to subside due to compaction of the subsurface aquifer. Our results are close to results obtained by PanGeo Project [39], as the authors obtained subsidence rate of $-1.21 \mathrm{~mm} /$ year around the same area, marked as PGGH_london_12.

In the Figure $8 \mathrm{~d}$, the north-western region exhibits distinct areas of uplift. The area marked has an extent of $82.6 \mathrm{~km}^{2}$ and 53,503 PS points. The mean uplift for this area is $0.21 \mathrm{~mm} /$ year. When we overlap the area on geo-referenced groundwater contour map obtained from EA [11], then it can be observed that the uplift area largely coincides with the area of the rise in groundwater levels. Additionally, the area has many lakes and ponds, like Brent reservoir and Viaduct pond, which helps with groundwater recharge. Thus, it can be concluded that the general uplift trend in the area marked is mainly because of groundwater rebound. However, an uplift of $0.21 \mathrm{~mm} /$ year is less and it cannot be said with certainty that for an area of nearly $83 \mathrm{~km}^{2}$, this value is significant. Additionally, it is not as certain that groundwater rebound is the only reason for uplift, and there may be various factors which determine the land movement, ranging from near-surface to deep-seated mechanisms and from less than a decade to over 100,000 years duration.

\subsection{Relationship between Ground Movement and Groundwater Change}

The ground movement obtained from PSInSAR largely depicts uplift in northern London and subsidence in southern London. Additionally, GRACE highlights that there is more groundwater loss from southern London as compared to northern London during our study period. The two results compliments each other as they represent the same water variations through compaction (InSAR) and mass variation (GRACE). However, there are some anomalies while comparing GRACE results with observed groundwater values for aquifer scale regions and it is difficult to derive a direct 
relationship between them. The main restriction of GRACE to manage groundwater has been described by Alley [55] and it specifies that it requires great modesty to view GRACE as a water management tool at aquifer scale. Nevertheless it provides a "big picture" view that is appropriate input for setting broad regional or national policies [53], a view for which our study provides further evidence.

Hence, to further study the relationship between ground movement and groundwater change we have taken observed groundwater data from boreholes provided by the EA. The EA publishes a "management of the London basin chalk aquifer" status report each year and we have extracted the data for key boreholes from graphs provided in the report for the year 2010.

The contour map for change in groundwater levels for London between the years 2000 and 2010 provided by the EA is consistent, and agrees well with the PSInSAR subsidence map of London obtained using Envisat data (Figure 9). The overall land movement pattern suggests an uplift in north London and subsidence in south London. This is consistent with the EA contour map for groundwater, which shows that there is an overall increase in groundwater level for the northern part and decrease in the southern part of the study area. The average water level rise is in the order of $7 \mathrm{~m}$ in north-west London and $4 \mathrm{~m}$ in central London, which corresponds to an average uplift of 31 and $20 \mathrm{~mm}$, respectively.
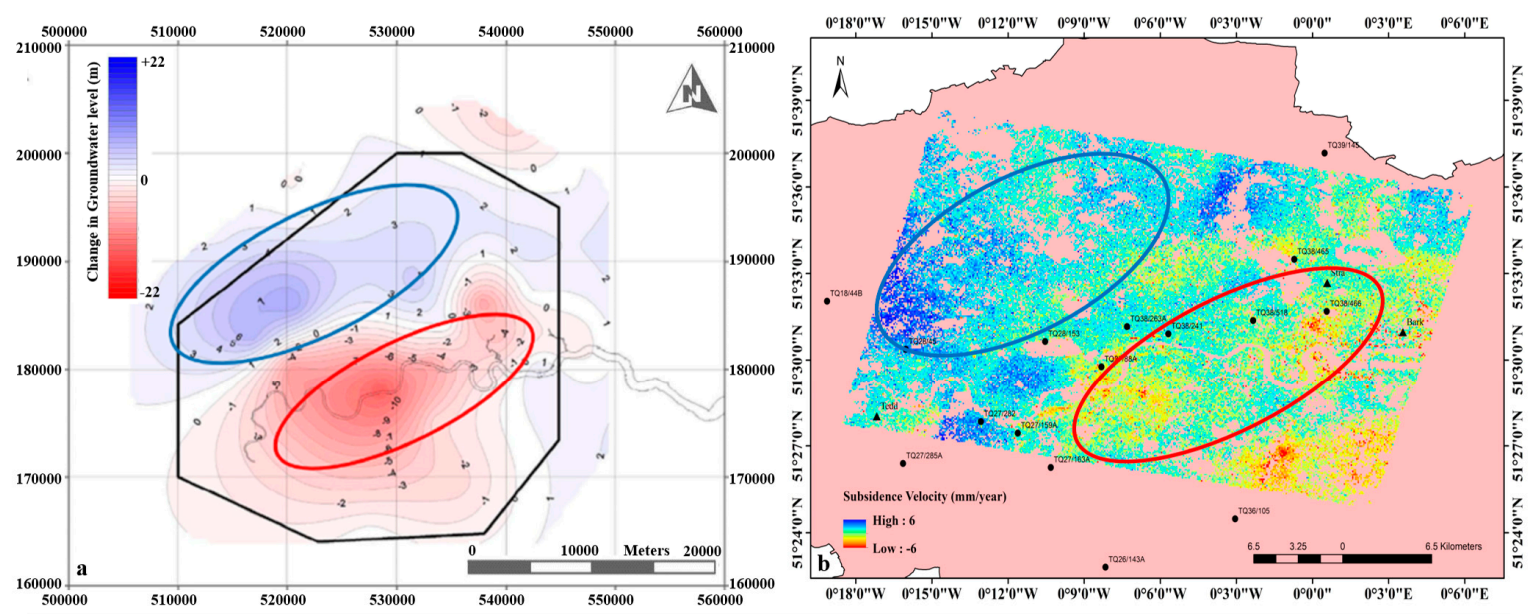

Figure 9. (a) Contour map for groundwater level change for London between 2002 and 2010, obtained from "management of the London basin chalk aquifer" status report, EA, 2010 [11]. (b) PSInSAR ground movement map for London between 2002 and 2010. The area marked with a blue oval in $(\mathbf{a}, \mathbf{b})$ highlights an increase in groundwater and land uplift, respectively, for north London; while the area marked with a red oval highlights a decrease in groundwater and land subsidence for south London.

It can be seen from Figure 9a that water level is decreasing to form a zone of water level fall crossing from south to east London, and there is prominent land subsidence in the corresponding area. Therefore, we can conclude that extraction or recharge of groundwater for a particular area directly contributes to the land subsidence or uplift of the corresponding area. Additionally, there might be a threat of saline intrusion in east London, in the area where the chalk outcrops around the River Thames from Greenwich to Woolwich. It can be observed from the contour map that groundwater flow is in a north-westerly direction, and thus water extraction could capture saline water if it enters the aquifer. Thus, there were restrictions applied to water abstraction licenses in this area [11].

Figure 9 validates that groundwater level directly influences the ground movement pattern. To further study both the phenomena, individual boreholes have been analysed (location marked in Figures 1 and 3). The time-series of groundwater variation for boreholes are compared to time-series of subsidence patterns at the corresponding location.

The land movement is an indirect effect of groundwater change, and hence it is smaller in magnitude than groundwater change. In addition, a time lag is expected in land movement when compared to the groundwater change. To obtain the subsidence at the location of a particular borehole, 
the average of all the Persistent Scatterers (PSs) present within $300 \mathrm{~m}$ of the borehole station was used. This is to address the challenge of obtaining a PS point at the exact location of borehole. As the groundwater level of a borehole will affect its nearby areas, it is suitable to take the contribution of nearby PS points for a particular borehole station.

Figure $10 \mathrm{a}-\mathrm{d}$ shows time-series variation for four key boreholes and their related subsidence. Three out of the four locations selected (i.e., TQ2788a (Ashley Gardens, Westminster), TQ27_159 (Ram Brewery, High street, Wandsworth), and TQ28_153 (Kensington Gardens)) show decreasing trends for both groundwater and ground movement (subsidence). Additionally, from Figure 3 we can see that all three boreholes are surrounded by reddish-yellow patches, indicating subsidence in the corresponding area. On the contrary, a dark blue patch can be seen in Figure 3 surrounding borehole TQ27_282 (I Stratford Grove, Putney) suggesting overall uplift. Temporal groundwater variation and subsidence trends from Figure 10d suggest the same. This pattern of land movement for all the four borehole stations can be attributed to the change in groundwater, as no other major contributing factors for this behaviour can be found.

Figure 1 shows the location of major faults in the study area. The faults might interfere with the groundwater flow, such that it can hinder the flow if fault material has low permeability, or it can act as flow conduits to promote the flow. The northern boundary fault has boreholes TQ38_241 (45-47 Gresham Street) and TQ38_263a (Victoria House, Southampton Row) on its southern and northern sides, respectively. The hydrographs from both the boreholes (Figure 11) shows comparable water levels and variation trends. The average change in groundwater for TQ38_241 (45-47 Gresham Street) is $-1.1233 \mathrm{~m}$ and that for TQ38_263a (Victoria House, Southampton Row) is $-1.279 \mathrm{~m}$. Similarly, the subsidence pattern for both the boreholes shows similar trends, with an average value of -0.70 and $-0.65 \mathrm{~mm} /$ year respectively. This suggests that this fault does not act as a barrier in this area.
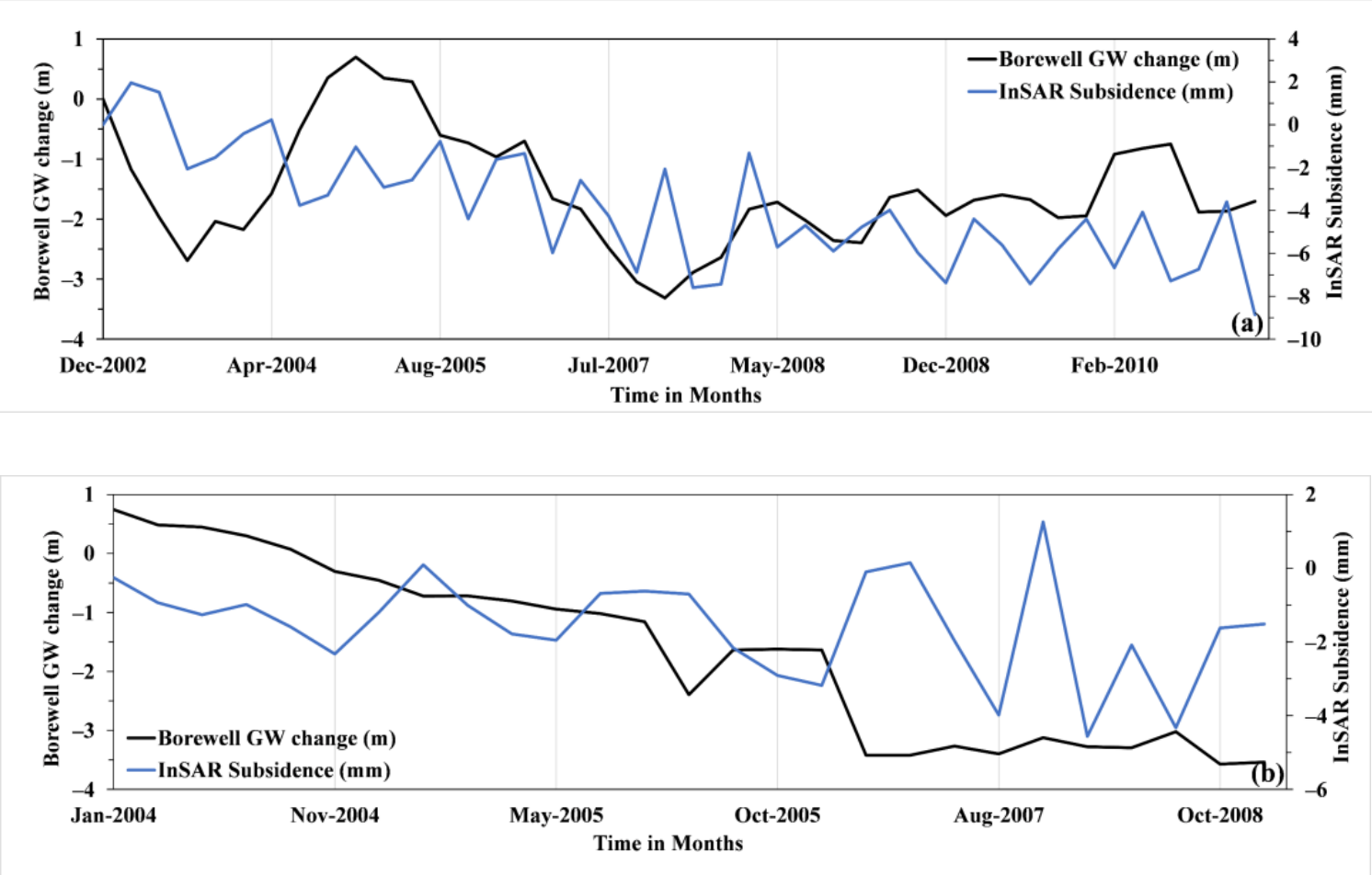

Figure 10. Cont. 

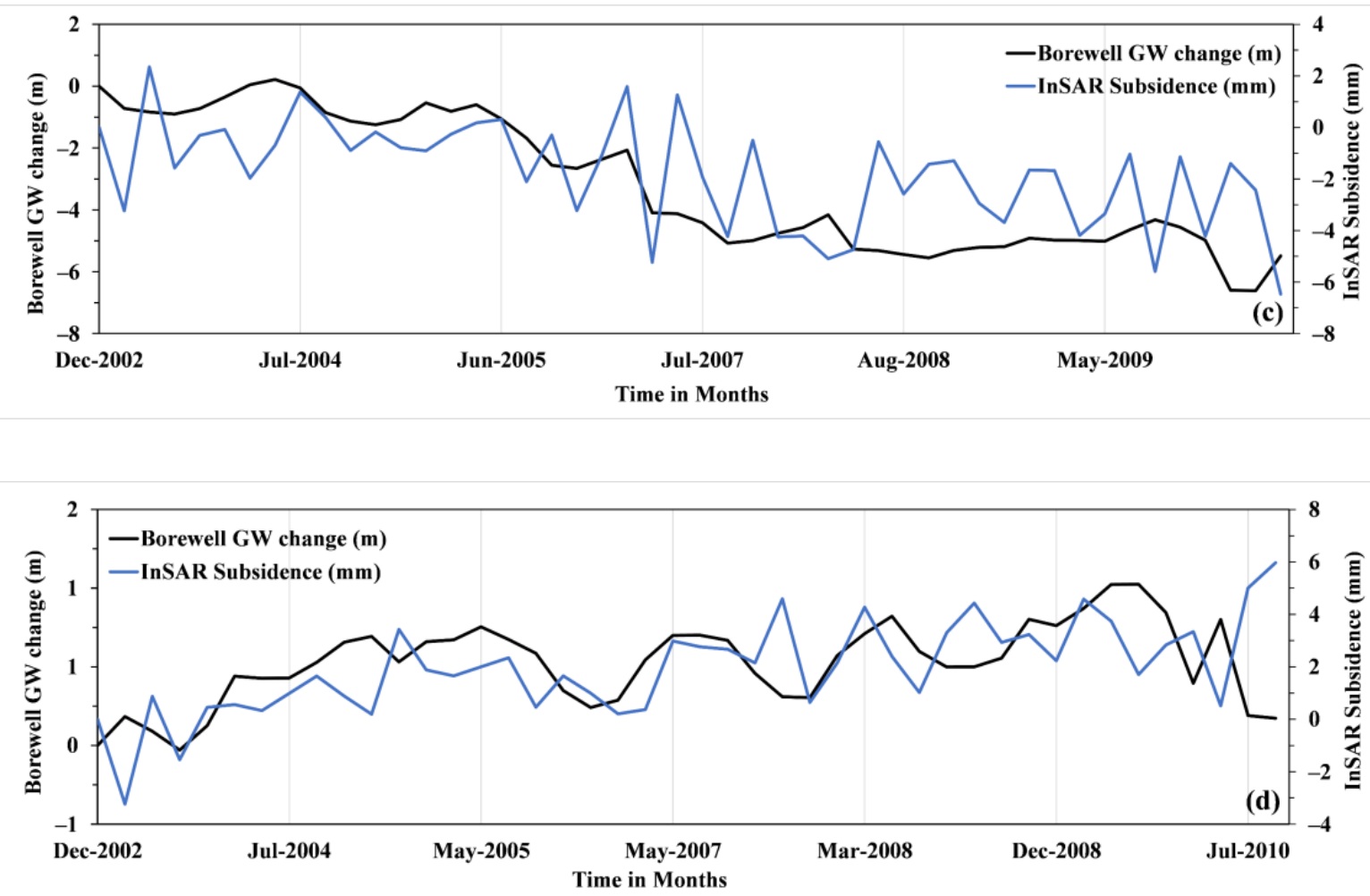

Figure 10. (a-d): Time-series variation of groundwater change (from borehole) and subsidence (from InSAR) for (a) TQ2788a (Ashley Gardens, Westminster), (b) TQ27_159 (Ram Brewery, High street, Wandsworth), (c) TQ28_153 (Kensington Gardens) and (d) TQ27_282 (I Stratford Grove, Putney).

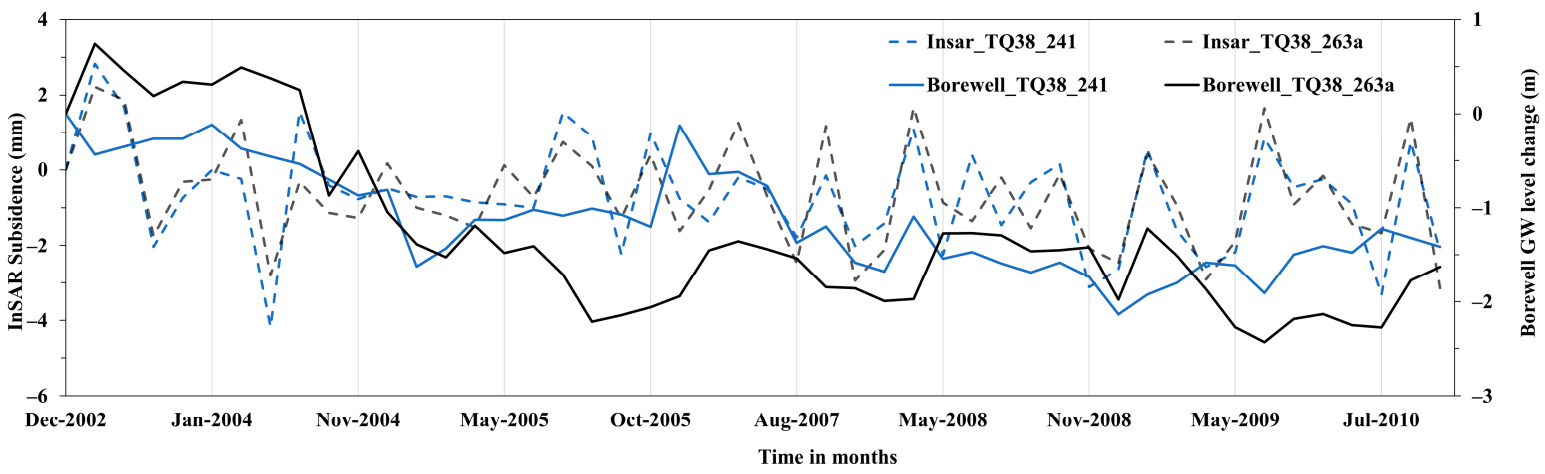

Figure 11. Subsidence and groundwater time-series for boreholes on either side of the northern boundary fault (i.e., TQ38_241 (45-47 Gresham Street) on the southern side and TQ38_263a (Victoria House, Southampton Row) on the northern side).

While looking at boreholes on either side of Greenwich fault (Figure 1), the two boreholes selected for this analysis were TQ48_2 (Victoria docks) and TQ47_90 (Charlton Obh). The average change in groundwater for TQ48_2 is $-1.386 \mathrm{~m}$ and that for TQ47_90 is $-0.197 \mathrm{~m}$. Similarly, the subsidence pattern for both the boreholes varies significantly with an average value of -0.634 and $-1.44 \mathrm{~mm} /$ year, respectively. This suggests that the Greenwich fault acts as a flow barrier. In addition, Rotherhithe Fault and Mitcham Fault at the centre of the basin are likely to act as flow barriers. However, there is no evidence for Wimbledon fault and Streatham fault to impede the groundwater flow [11].

\section{Conclusions}

In this study, we explored the suitability of monitoring ground movement using PSInSAR subsidence and GNSS data for London between December 2002 and September 2010. We also 
monitored groundwater variation using GRACE gravity anomalies and observed boreholes for London for the same time period.

We observed that the ground movement in London is distinctly uneven and non-linear. The ground movement in the north-western part of the study area is positive, implying land uplift. On the contrary, the ground movement in the south-eastern part of the study area is negative, implying land subsidence. The average subsidence in the study area is found to be $-0.176 \mathrm{~mm} /$ year. By statistically analysing the average subsidence velocities, it is observed that the standard deviation of $98.22 \%$ of the PS points are less than $5 \mathrm{~mm} /$ year, and that for overall PSInSAR subsidence is $0.665 \mathrm{~mm} /$ year. The InSAR subsidence values were validated using GNSS data. The two-sample $t$-test provides enough evidence that GNSS up values are in close agreement with the obtained InSAR subsidence values, thus demonstrating that the PSInSAR is an efficient way to survey ground movement in London.

The groundwater changes obtained from GRACE demonstrates a decreasing tendency and the average groundwater loss from GRACE was found to be $9.003 \mathrm{MCM} /$ year. The best-fit line for the temporal groundwater variation from GRACE has a negative slope, indicating groundwater depletion. The volumetric change of groundwater derived from GRACE data accounted for $60 \%$ of the total change in the report from the Environment Agency. In addition, the GRACE-derived temporal time-series showed seasonal and annual variations.

Different reasons for site-specific land movement patterns were discussed. The major factor which was consistent with spatial ground movement is the spatial change in the groundwater. In addition, ground movement was studied in conjunction with groundwater variation obtained from various boreholes. We suggest that when a large volume of groundwater is extracted from an aquifer, it results in compaction of underlying aquifer material and, in turn, is responsible for land subsidence, and, in contrast, recharge or rebound of groundwater results in land upliftment.

The spatial resolution for GRACE is low, while that of InSAR is high. The PSInSAR method is excellent for studying spatial variation of groundwater, and GRACE is excellent for studying temporal variation of groundwater. With new processing algorithms and the GRACE follow-on mission, the resolution is expected to improve. In addition, the increasing coverage and availability of SAR data should enhance the accuracy of subsidence mapping. With these updated data sets, it will be suitable to read InSAR and GRACE results at the same resolution and make a direct statistical comparison for future studies. Overall, the study of InSAR and GRACE in conjunction provides an interesting technology for spatial and temporal mapping of groundwater and ground movement.

Author Contributions: Conceptualization, V.A., R.L.G. and S.M.; data curation, V.A., R.L.G. and S.M.; formal analysis, V.A. and A.K.; funding acquisition, V.A., R.L.G. and S.M.; investigation, V.A., R.L.G. and S.M.; methodology, V.A., A.K., R.L.G. and S.M.; resources, V.A.; software, V.A. and A.K.; supervision, R.L.G. and S.M.; validation, R.L.G. and S.M.; visualization, V.A., A.K., R.L.G. and S.M.; writing-original draft, V.A.; writing-review and editing, V.A., R.L.G. and S.M. All authors have read and agreed to the published version of the manuscript.

Funding: The research was funded by the University of Nottingham Faculty of Engineering Research Excellence PhD scholarship.

Acknowledgments: The authors would like to thank the European Space Agency (ESA) for providing access to SARscape software for processing of InSAR data through Eohops programme. We would also like to thank the EA for providing "management of the London basin chalk aquifer" status report 2010. The services of the Natural Environment Research Council (NERC) British Isles continuous GNSS Facility (BIGF), www.bigf.ac.uk, in providing archived GNSS data (and/or products) to this study, are gratefully acknowledged.

Conflicts of Interest: The authors declare no conflict of interest.

\section{References}

1. Tiwari, V.M.; Wahr, J.; Swenson, S. Dwindling groundwater resources in northern India, from satellite gravity observations. Geophys. Res. Lett. 2009, 36. [CrossRef]

2. Wolf, L.; Morris, B.; Burn, S. Urban Water Resources Toolbox-Integrating Groundwater into Urban Water Management. Water Intell. Online 2015, 5, 395-403. [CrossRef] 
3. Zheng, M.; Deng, K.; Fan, H.; Du, S. Monitoring and analysis of surface deformation in mining area based on InSAR and GRACE. Remote Sens. 2018, 10, 1392. [CrossRef]

4. Karl, T. Theory of consolidation. Theor. Soil Mech. 1943, 265-296.

5. Riley, F.S. Analysis of Borehole Extensometer Data from Central California. Land Subsid. 1969, 2, $423-431$.

6. Helm, D.C. One-dimensional simulation of aquifer system compaction near Pixley, California: 1. Constant parameters. Water Resour. Res. 1975, 11, 465-478. [CrossRef]

7. BGS. Industrial and Urban Pollution of Groundwater. UK Groundw. Forum 2013. Available online: http://www.groundwateruk.org/downloads/industrial_and_urban_pollution_of_groundwater.pdf (accessed on 20 September 2020).

8. Bonì, R.; Cigna, F.; Bricker, S.; Meisina, C.; McCormack, H. Characterisation of hydraulic head changes and aquifer properties in the London Basin using Persistent Scatterer Interferometry ground motion data. J. Hydrol. 2016, 540, 835-849. [CrossRef]

9. Royse, K.R.; De Freitas, M.; Burgess, W.G.; Cosgrove, J.; Ghail, R.C.; Gibbard, P.; King, C.; Lawrence, U.; Mortimore, R.N.; Owen, H.; et al. Geology of London, UK. Proc. Geol. Assoc. 2012, 123, 22-45. [CrossRef]

10. Jones, M.A.; Hughes, A.G.; Jackson, C.R.; Van Wonderen, J.J. Groundwater resource modelling for public water supply management in London. Geol. Soc. Spec. Publ. 2012, 364, 99-111. [CrossRef]

11. EA. Management of the London Basin Chalk Aquifer. Status Report 2010. Environ. Agency Engl. Wales Thames Reg. Rep. 2010. Available online: https://assets.publishing.service.gov.uk/government/uploads/ system/uploads/attachment_data/file/735451/2018_Final.pdf (accessed on 28 August 2020).

12. Huang, J.; Deng, K.; Fan, H.; Yan, S. An improved pixel-tracking method for monitoring mining subsidence. Remote Sens. Lett. 2016, 7, 731-740. [CrossRef]

13. Fialko, Y.; Simons, M.; Agnew, D. The complete (3-D) surface displacement field in the epicentral area of the 1999 Mw 7.1 Hector Mine earthquake, California, from space geodetic observations. Geophys. Res. Lett. 2001, 28, 3063-3066. [CrossRef]

14. Wang, Y.; Wang, L.; Zhang, Y.; Yang, T. Investigation of snow cover change using multi-temporal PALSAR InSAR data at Dagu Glacier, China. In Proceedings of the International Geoscience and Remote Sensing Symposium (IGARSS), Milan, Italy, 26-31 July 2015.

15. Fan, H.; Gao, X.; Yang, J.; Deng, K.; Yu, Y. Monitoring mining subsidence using a combination of phase-stacking and offset-tracking methods. Remote Sens. 2015, 7, 9166-9183. [CrossRef]

16. Dai, K.; Liu, G.; Li, Z.; Li, T.; Yu, B.; Wang, X.; Singleton, A. Extracting vertical displacement rates in Shanghai (China) with multi-platform SAR images. Remote Sens. 2015, 7, 9542-9562. [CrossRef]

17. Fan, H.D.; Cheng, D.; Deng, K.Z.; Chen, B.Q.; Zhu, C.G. Subsidence monitoring using D-InSAR and robability integral prediction modelling in eep mining areas. Surv. Rev. 2015, 47, 438-445. [CrossRef]

18. Rodell, M.; Velicogna, I.; Famiglietti, J.S. Satellite-based estimates of groundwater depletion in India. Nature 2009, 460, 999-1002. [CrossRef]

19. Ramillien, G.; Frappart, F.; Seoane, L. Space Gravimetry Using GRACE Satellite Mission: Basic Concepts. In Microwave Remote Sensing of Land Surfaces: Techniques and Methods; Elsevier BV: Amsterdam, The Netherlands, 2016; pp. 285-302. [CrossRef]

20. Zaitchik, B.F.; Rodell, M.; Reichle, R.H. Assimilation of GRACE terrestrial water storage data into a land surface model: Results for the Mississippi River basin. J. Hydrometeorol. 2008, 9, 535-548. [CrossRef]

21. Wang, X.; De Linage, C.; Famiglietti, J.; Zender, C.S. Gravity Recovery and Climate Experiment (GRACE) detection of water storage changes in the Three Gorges Reservoir of China and comparison with in situ measurements. Water Resour. Res. 2011, 47. [CrossRef]

22. Guo, J.; Zhou, L.; Yao, C.; Hu, J. Surface subsidence analysis by multi-temporal InSAR and GRACE: A case study in Beijing. Sensors (Switzerland) 2016, 16, 1495. [CrossRef]

23. Tourian, M.J.; Elmi, O.; Chen, Q.; Devaraju, B.; Roohi, S.; Sneeuw, N. A spaceborne multisensor approach to monitor the desiccation of Lake Urmia in Iran. Remote Sens. Environ. 2015, 156, 349-360. [CrossRef]

24. Longuevergne, L.; Wilson, C.R.; Scanlon, B.R.; Crétaux, J.F. GRACE water storage estimates for the middle east and other regions with significant reservoir and lake storage. Hydrol. Earth Syst. Sci. 2013, 17, 4817-4830. [CrossRef]

25. Castellazzi, P.; Martel, R.; Rivera, A.; Huang, J.; Pavlic, G.; Calderhead, A.I.; Chaussard, E.; Garfias, J.; Salas, J. Groundwater depletion in Central Mexico: Use of GRACE and InSAR to support water resources management. Water Resour. Res. 2016, 52, 5985-6003. [CrossRef] 
26. Du, Z.; Ge, L.; Ng, A.H.M.; Li, X. Time series interferometry integrated with groundwater depletion measurement from grace. In Proceedings of the International Geoscience and Remote Sensing Symposium (IGARSS), Beijing, China, 10-15 July 2016.

27. Mathers, S.J.; Burke, H.F.; Terrington, R.L.; Thorpe, S.; Dearden, R.A.; Williamson, J.P.; Ford, J.R. A geological model of London and the Thames Valley, southeast England. Proc. Geol. Assoc. 2014, 125, 373-382. [CrossRef]

28. Ford, J.R.; Mathers, S.J.; Royse, K.R.; Aldiss, D.T.; Morgan, D.J.R. Geological 3D modelling: Scientific discovery and enhanced understanding of the subsurface, with examples from the UK. Z. Dtsch. Ges. Geowiss. 2010, 161, 205-218. [CrossRef]

29. UK Groundwater forum. Groundwater of hidden assest. Thames Groundw. Scheme. Inst. Civ. Eng. Lond. 1998. Available online: http://www.groundwateruk.org/ (accessed on 15 September 2020).

30. Thames Water. Final Water Resources Management Plan. Exec. Summ. 2015. Available online: https:/www.thameswater.co.uk/media-library/home/about-us/regulation/water-resources/technicalreport/executive-summary.pdf (accessed on 16 September 2020).

31. de Freitas, M.H. Geology; its principles, practice and potential for Geotechnics. Q. J. Eng. Geol. Hydrogeol. 2009, 42, 397-441. [CrossRef]

32. Bloomfield, J.P.; Bricker, S.H.; Newell, A.J. Some relationships between lithology, basin form and hydrology: A case study from the Thames basin, UK. Hydrol. Process. 2011, 25, 2518-2530. [CrossRef]

33. Price, M. Fluid flow in the Chalk of England. Geol. Soc. Spec. Publ. 1987, 34, 141-156. [CrossRef]

34. Gunn, J.; Downing, R.A.; Price, M.; Jones, G.P. The Hydrogeology of the Chalk of North-West Europe. Trans. Inst. Br. Geogr. 1995, 20, 397. [CrossRef]

35. Price, M.; Bird, M.J.; Foster, S.S.D. Chalk Pore-Size Measurements and their Significance. Water Serv. 1976, 80, 596-600. [CrossRef]

36. Bloomfield, J.P.; Brewerton, L.J.; Allen, D.J. Regional trends in matrix porosity and dry density of the Chalk of England. Q. J. Eng. Geol. 1995, 28, S131-S142. [CrossRef]

37. European Commission. Mapping Guide for a European Urban Atlas. Available online: https://land. copernicus.eu/user-corner/technical-library/urban-atlas-mapping-guide (accessed on 18 September 2020).

38. Hooper, A.J. A multi-temporal InSAR method incorporating both persistent scatterer and small baseline approaches. Geophys. Res. Lett. 2008, 35. [CrossRef]

39. Cigna, F.; Jordan, H.; Bateson, L.; McCormack, H.; Roberts, C. Natural and Anthropogenic Geohazards in Greater London Observed from Geological and ERS-1/2 and ENVISAT Persistent Scatterers Ground Motion Data: Results from the EC FP7-SPACE PanGeo Project. Pure Appl. Geophys. 2015, 172, 2965-2995. [CrossRef]

40. Sarmap. PS Tutorial. 2014. Available online: http://www.sarmap.ch/tutorials/PS_Tutorial_V_0_9.pdf (accessed on 30 September 2020).

41. Sarmap. SARscape Help Manual. 2014. Available online: https://www.13harrisgeospatial.com/docs/pdf/ sarscape_5.1_help.pdf (accessed on 30 September 2020).

42. Tapley, B.D.; Bettadpur, S.; Watkins, M.; Reigber, C. The gravity recovery and climate experiment: Mission overview and early results. Geophys. Res. Lett. 2004, 31. [CrossRef]

43. Wahr, J.; Molenaar, M.; Bryan, F. Time variability of the Earth's gravity field: Hydrological and oceanic effects and their possible detection using GRACE. J. Geophys. Res. Solid Earth 1998, 103, 30205-30229. [CrossRef]

44. Dahle, C.; Murböck, M. Post-processed GRACE/GRACE-FO Geopotential GSM Coefficients COST-G RL01 (Level-2B Product). GFZ Data Serv. 2020. [CrossRef]

45. Horvath, A.; Murböck, M.; Pail, R.; Horwath, M. Decorrelation of GRACE time variable gravity field solutions using full covariance information. Geosciences 2018, 8, 323. [CrossRef]

46. Dobslaw, H.; Bergmann-Wolf, I.; Dill, R.; Poropat, L.; Thomas, M.; Dahle, C.; Esselborn, S.; König, R.; Flechtner, F. A new high-resolution model of non-tidal atmosphere and ocean mass variability for de-aliasing of satellite gravity observations: AOD1B RL06. Geophys. J. Int. 2017, 211, 263-269. [CrossRef]

47. Ek, M.B.; Mitchell, K.E.; Lin, Y.; Rogers, E.; Grunmann, P.; Koren, V.; Gayno, G.; Tarpley, J.D. Implementation of Noah land surface model advances in the National Centers for Environmental Prediction operational mesoscale Eta model. J. Geophys. Res. D Atmos. 2003, 108. [CrossRef]

48. Dai, Y.; Zeng, X.; Dickinson, R.E.; Baker, I.; Bonan, G.B.; Bosilovich, M.G.; Denning, A.S.; Dirmeyer, P.A.; Houser, P.R.; Niu, G.; et al. The common land model. Bull. Am. Meteorol. Soc. 2003, 84, 1013-1024. [CrossRef]

49. Koster, R.D.; Suarez, M.J. Energy and Water Balance Calculations in the Mosaic LSM; NASA: Greenbelt, MD, USA, 1996. 
50. Liang, X.; Lettenmaier, D.P.; Wood, E.F.; Burges, S.J. A simple hydrologically based model of land surface water and energy fluxes for general circulation models. J. Geophys. Res. 1994, 99, 14415-14428. [CrossRef]

51. Ellison, R.A.; Woods, M.A.; Allen, D.J.; Forster, A.; Pharaoh, T.C.; King, C. Geology of London. Special Memoir for 1:50 000 Geological sheets 256 (North London), 257 (Romford), 270 (South London) and 271 (Dartford) (England and Wales). Geol. Mag. 2004. Available online: http://nora.nerc.ac.uk/id/eprint/509917/ (accessed on 3 September 2020).

52. Kusche, J.; Schrama, E.J.O. Surface mass redistribution inversion from global GPS deformation and Gravity Recovery and Climate Experiment (GRACE) gravity data. J. Geophys. Res. Solid Earth 2005, 110. [CrossRef]

53. Famiglietti, J.S.; Rodell, M. Water in the balance. Science 2013, 340, 1300-1301. [CrossRef]

54. Standing, J.; Selman, R. Building Response to Tunnelling-Case studies from construction of the Jubilee Line Extension, London. Ciria 2001. Available online: https://www.ciria.org//ProductExcerpts/SP200.aspx (accessed on 10 September 2020).

55. Alley, W.M.; Konikow, L.F. Bringing GRACE Down to Earth. Groundwater 2015, 53, 826-829. [CrossRef]

Publisher's Note: MDPI stays neutral with regard to jurisdictional claims in published maps and institutional affiliations.

(C) 2020 by the authors. Licensee MDPI, Basel, Switzerland. This article is an open access article distributed under the terms and conditions of the Creative Commons Attribution (CC BY) license (http://creativecommons.org/licenses/by/4.0/). 